\title{
Sugarcane Breeding in Reunion: Challenges, Achievements and Future Prospects
}

\author{
Thomas Dumont $^{1} \cdot$ Laurent Barau $^{1} \cdot$ Audrey Thong-Chane ${ }^{1} \cdot$ Jordan Dijoux $^{1}$ • \\ Mathilde Mellin $^{1} \cdot$ Jean Daugrois $^{2,3} \cdot$ Jean-Yves Hoarau $^{1,4,5}$
}

Received: 25 November 2020/Accepted: 29 April 2021/Published online: 17 May 2021

(C) The Author(s) 2021

\begin{abstract}
All over the world, sugarcane breeding programs are developing new, high-yielding cultivars that are resistant to major diseases to improve the profitability and sustainability of the sugar-energy industries they serve. In Reunion Island, sugarcane genetic improvement efforts began in 1929. Many challenges had to be overcome. Continuous breeding efforts have been made to develop varietal resistances to control some major diseases and are still going on today. Given the extreme agroclimatic diversity that characterizes the different production areas of the industry, it was necessary to gradually develop a large network of seven decentralized breeding programs to support genetic progress throughout the whole industry. This article provides an overview of the sugarcane breeding program of Reunion. It describes historical achievements and gives detailed information about germplasm development, variety exchanges, breeding program and selection scheme and procedures. A review is also made on applied genetics research activities supporting variety improvement. Further progress depends on the optimized functioning of the current breeding program, which has never been so largely extended in terms of target
\end{abstract}

Jean-Yves Hoarau

jean-yves.hoarau@ercane.re

1 eRcane, 29 rue d'Emmerez de Charmoy, BP 60315, 97490

Sainte-Clotilde, La Réunion, France

2 CIRAD, UMR PHIM, 34398 Montpellier, France

3 PHIM, Univ. Montpellier, CIRAD, INRAE, l'Institut Agro, Montpellier, France

4 CIRAD, UMR AGAP, 97490 Saint-Clotilde, La Réunion, France

5 AGAP, Univ. Montpellier, CIRAD, INRAE, l'Institut Agro, Montpellier, France environments. The article discusses prospects of genomics breeding applications in the complex genetic context of sugarcane, which will require large multidisciplinary collaborations.

Keywords Sugarcane breeding · Reunion ·

Selection program - Genetics research

\section{Introduction}

Sugarcane is still the first cultivated crop in Reunion Island. Today it supplies two large agro-industrial complexes made up of sugar factories, cogeneration plants and distilleries, which produce sugar, electricity and ethanol, respectively (Caderby et al. 2014). The sugarcane industry is a major sector of Reunion's economy in terms of jobs and income, along with the tourism sector. Sugarcane is currently grown all around the Island on over 23,000 ha. The average cane yield is $80-85$ tonnes/ha (Table 1). The industry spans contrasting agroclimatic zones, encompassing tropical and subtropical climatic conditions of production, due to a relatively large thermal gradient in relationship with the altitude of cane area, from sea level up to $1000 \mathrm{~m}$ in the West leeward Island (Fig. 1). Agronomic potential varies considerably between cultivation areas (from 60 to 130 tonnes/ha cane yield). This variability in cane yield is caused by differences in average annual rainfall (ranging from $700 \mathrm{~mm}$ in dry West leeward lands up to 4,000 $\mathrm{mm}$ in East windward lands), by differences in average temperatures (depending on altitude level), and by differences in soil fertility (Pouzet et al. 1997). Cane productivity varies on average, by a factor of two between the leeward highlands, which suffer from thermal and water stresses, and the most favorable coastal 
Table 1 Basic statistics and information of current sugarcane industry in Réunion

Current total area growing sugarcane

Average yield in past five years ( $t / h a)$

Average commercial cane sugar content $(\%)$

Average number of ratoon crops

Total sugar production

Average number of growers

$\%$ of area mechanically harvested

Incl. chopper harvesters

Incl. small local whole cane harvesters

Number of sugar mills

Major diseases and pests

Major abiotic stresses

\section{3,000 ha}

85

$13.8 \%$

$10-12$

200,000 tonnes

2800

$36 \%$

$20 \%$

$16 \%$

2

Leaf scald, gumming disease, smut, orange and brown rusts Either thermal, hydric or edaphic ${ }^{\mathrm{a}}$

${ }^{a}$ Depending on locations: see Fig. 1 and related text

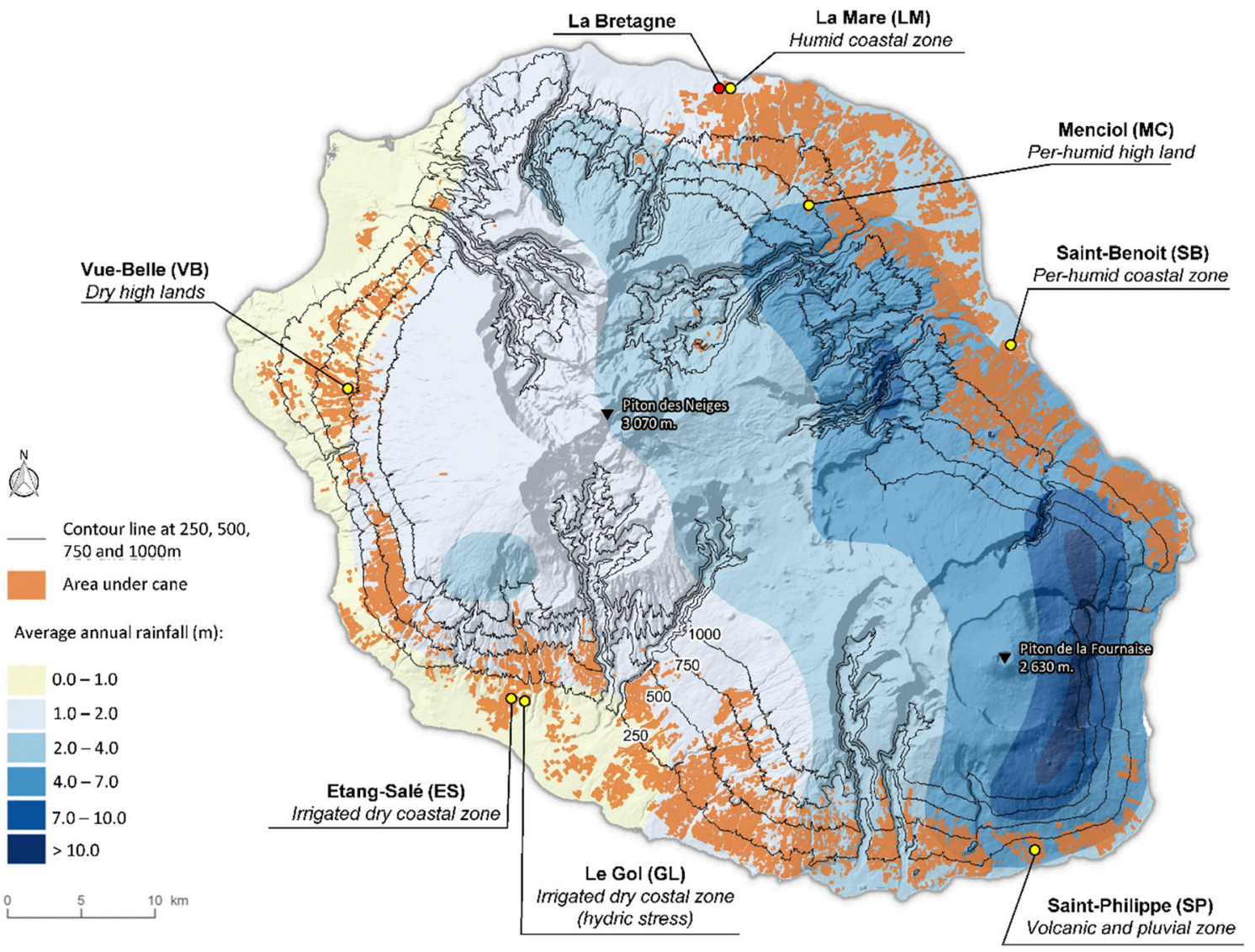

Fig. 1 Variability of sugarcane cultivation conditions in Reunion Island due to varying annual rainfall and altitude/thermal gradients and location of the seven eRcane decentralized sugarcane selection programs. Sugarcane cultivation areas (pictured in brown color) are scattered all around the Island in many different agroclimatic

windward lands. This agroclimatic diversity of growing environments in Reunion represents a challenging situation for breeding and justifies the development of a selection environments, which represents a challenging situation for breeding. The seven selection stations are located in different contrasted environments. In each one, eRcane conducts a complete selection scheme since seedling stage in order to select for locally adapted varieties

program decentralized in many representative cultivation areas in order to select varieties with local adaptation. 
Since almost a century ago, eRcane research institute ( www.ercane.re) has had a mandate to develop new highyielding sugarcane cultivars for Reunion that perform well over successive harvests and are resistant or tolerant to the major diseases (Table 2). This private institute has actively contributed to increasing production of sugarcane sector, enhancing its profitability and sustainability (Hoarau et al. 2002a). The varietal development program has continuously adapted to the evolving expectations and challenges that Reunion's cane industry has experienced over decades. It has regularly delivered new elite germplasm and sugarcane cultivars improved for farming and industrial profits. It constitutes the cornerstone of a productive cane industry on arable lands that are limited by urban encroachment and which hence need to be cultivated in more profitable and sustainable ways. The eRcane breeding program aims at progressively improving its working germplasm for traits related to cane yield and quality, ratooning ability and for local adaptation to diverse environments. It is based on sexual recombination between germplasm of interest in a main commercial hybridization program and in an exploratory base broadening program (eRcane 2009). A central hybridization facility located at La Bretagne continuously produces new populations of seedlings which are then tested in seven concurrent sub-programs of selection located in the most representative and contrasting agroclimatic zones of the industry (Fig. 1). The selection scheme which starts with 100,000 seedlings consists of five successive clonal selection phases which spans a total of 14 years before the identification of a few superior precommercial varieties (Table 3 ). The management of the program in terms of breeding decision-making and resource allocation is supported by statistical analysis of trial data using mixed modeling approaches of traits of interest (a presentation of mixed models is given by Hoarau et al. 2021). Analyses are always performed at individual trial level for ordinary selection decision advancement, with models possibly designed to adjust for spatial variability in order to improve experimental precision of trials (Hoarau et al. 2019). Analyses are also periodically conducted at large population levels in meta-analyses of trials within selection environments (Dumont et al. 2019) or across environments (Guilly et al. 2017) to estimate some genetic or statistical parameters useful for optimizing the long-term management of the program.

The breeding program of Reunion conducted by eRcane also benefits from continuous scientific collaborations with a few research units of the French agricultural research organization working for the sustainable development of tropical regions, so-called CIRAD (Centre de coopération Internationale en Recherche Agronomique pour le Développement). These units, which are working on sugarcane, are based either in Reunion or in Mainland France. These collaborations are intended to support the efficiency of the breeding program of Reunion's sugarcane industry. They include (i) Visacane quarantine services to safely exchange varieties between Reunion and foreign countries (http://visacane.cirad.fr/en/); (ii) scientific expertise in phytopathology for mastering of important local diseases and (iii) supportive research in applied genetics and marker-based approaches.

This article describes (i) the history of the sugarcane breeding program of Reunion, (ii) its current decentralized organization, (iii) germplasm development and use in breeding, (iv) selection objectives and detailed information

Table 2 Organizations involved in sugarcane improvement in Reunion

\begin{tabular}{lcc}
\hline Organization & Funding source & Key activities \\
\hline eRcane & $\begin{array}{c}\text { Mainly private funds from } \\
\text { Reunion sugarcane industry's } \\
\text { stakeholders }\end{array}$ & $\begin{array}{c}\text { Germplasm maintenance and } \\
\text { development, pre-breeding, } \\
\text { commercial breeding, } \\
\text { experimental selection, } \\
\text { quantitative and marker-based } \\
\text { CIRAD }\end{array}$ \\
& $\begin{array}{c}\text { Mainly public funds from local analysis with CIRAD } \\
\text { and national authorities }\end{array}$ & $\begin{array}{c}\text { Pest and disease researches, } \\
\text { quarantine services, genetic } \\
\text { diversity, genetics and genomics } \\
\text { research }\end{array}$ \\
\hline
\end{tabular}


Table 3 Progression of selection in the decentralized selection programs of Réunion

\begin{tabular}{|c|c|c|c|c|c|c|c|}
\hline $\begin{array}{l}\text { Selection } \\
\text { stage }\end{array}$ & $\begin{array}{l}\text { Clones } \times \text { site } \\
\text { (total) }\end{array}$ & Trial design & $\begin{array}{l}\text { Plot area } \\
\left(\mathrm{m}^{2}\right)\end{array}$ & $\begin{array}{l}\text { Number of } \\
\text { replicates }\end{array}$ & $\begin{array}{l}\text { Number of } \\
\text { crop-years }\end{array}$ & $\begin{array}{l}\text { Selection } \\
\text { rate }(\%)\end{array}$ & Selection criteria \\
\hline $\begin{array}{l}\text { Stage } 1 \\
\quad \text { Seedlings }\end{array}$ & $\begin{array}{r}15000 \times 7 \\
(100000)\end{array}$ & $\begin{array}{l}\text { Family partially } \\
\text { replicated }\end{array}$ & & & 1 & 12 & Family aspect, disease resistance \\
\hline $\begin{array}{l}\text { Stage } 2 \\
\text { '1 row' }\end{array}$ & $\begin{array}{r}2000 \times 7 \\
(14000)\end{array}$ & Grid-plot design & 4.5 & & 2 & 7 & $\begin{array}{l}\text { Visual aspect }{ }^{\mathrm{b}} \text {, brix in } 1 \text { st ratoon, } \\
\text { disease resistance }\end{array}$ \\
\hline $\begin{array}{l}\text { Stage } 3 \\
\text { '2 rows' }\end{array}$ & $\begin{array}{c}120 \times 7 \\
(840)\end{array}$ & Alpha design & 15 & 2 & 3 & 21 & $\begin{array}{l}\text { Visual aspect }{ }^{\mathrm{b}} \text {, disease resistance, } \\
\text { sugar yield, ratoon ability }\end{array}$ \\
\hline $\begin{array}{l}\text { Stage } 4 \\
\text { '3 rows' }\end{array}$ & $25 \times 7(175)$ & $\begin{array}{l}\text { Randomized } \\
\text { complete block } \\
\text { design }\end{array}$ & 45 & 3 & 4 & 14 & $\begin{array}{l}\text { Visual aspect }{ }^{\mathrm{b}} \text {, disease resistance, } \\
\text { sugar yield, ratoon ability }\end{array}$ \\
\hline $\begin{array}{l}\text { Stage } 5 \\
\text { 'MET }^{\mathrm{a}} \text {, }\end{array}$ & $\begin{array}{l}25 \text { clones per } \\
\text { MET }^{\mathrm{a}}\end{array}$ & $\begin{array}{l}\text { Randomized } \\
\text { complete block } \\
\text { design }\end{array}$ & 45 & 4 & 4 & & $\begin{array}{l}\text { Visual aspect }{ }^{\mathrm{b}} \text {, disease resistance, } \\
\text { sugar yield, ratoon ability }\end{array}$ \\
\hline
\end{tabular}

${ }^{\mathrm{a}}$ MET: multienvironment trials

${ }^{\mathrm{b}}$ See paragraph 5.3 for detailed information

about the selection program and methods and (v) genetic research activities in support of variety improvement.

\section{Almost of Century of Breeding Efforts}

\section{Pioneer Times}

eRcane is the research and development institute of Reunion Island specialized in sugarcane (www.ercane.re). Its R\&D activities cover a broad range of agronomic and industrial projects devoted to the development of the sugarcane sector and to its profitability and sustainability (eRcane 2009). eRcane was created in 1929 by the local Sugar Producers' Syndicate (Hoarau et al. 2002a) after the outbreak of a serious mosaic epidemic in the late 1920s. This disease caused heavy economic losses in both West and South regions of Reunion Island that represented half of the whole cultivation area (Kopp and D'Emmerez de Charmoy 1932). The average yield in Reunion had collapsed to 2 tonnes of sugar per hectare. At that time, cultivated varieties were all noble canes (Saccharum officinarum), which turned out to be susceptible to the disease that was introduced into the island at the beginning of the twentieth century when importing infected cuttings of new varieties. At that time, many producing regions around the world were also severely affected by mosaic epidemics (such as in Argentina, South Africa, Louisiana, Porto-Rico and Cuba). The initial mission of the breeding program of eRcane was to restore the health and yields of sugarcane fields. This was done by Donald D'Emmerez de Charmoy, the first sugarcane breeder of Reunion, who was initially trained at Coimbatore, India in all sugarcane breeding aspects (D’Emmerez de Charmoy 1929). From the 1930s, he introduced a few wild germplasm (S. spontaneum) and dozens of new interspecific varieties from all the pioneering breeding programs that existed at that time (D'Emmerez de Charmoy 1962). Among these varieties were some legendary POJ varieties of Indonesia and $\mathrm{CO}$ varieties of India, which had been recently selected from the first 'nobilisation' programs ${ }^{1}$ as well as many promising varieties of other origins (mainly from Barbados, Mauritius, South Africa, Hawaii and Canal Point). Local growers immediately adopted the best-adapted varieties to overcome mosaic epidemic and restore yields of their fields. Some of these well-known interspecific founders used by many breeding programs around the world (among which POJ36, POJ2725, POJ2878, Co214 and Co281) were first combined in Reunion from the 1930s with 'Uba Marot' ( $S$. sinense) a natural interspecific variety, resistant to mosaic and producing abundant tillering. This first generation of crosses and the next two generations of backcrosses to cultivated clones (D'Emmerez de Charmoy 1953, 1962) allowed selection of a dozen highly productive locally bred varieties in the two decades after establishment of the program. Cultivation of these locally bred cultivars named ' $\mathrm{R}$ ' cultivars (such as R331, R337, R366, R380, R397) and a few foreign ones contributed to the local 'sugar boom' after the Second World War (Hoarau et al. 2002a). Intercrossing between these first locally bred cultivars and that thereafter between their successive products were enriched with high-yielding founders imported from Hawaii (such as H32/8560 and H39/3633) from the 1950s,

\footnotetext{
${ }^{1}$ Interspecific hybridizations between $S$. officinarum (the 'noble' species) and $S$. spontaneum (the 'wild' species) followed by few backcrosses onto the 'noble' species.
} 
and provided the foundations of the present-day working germplasm of Reunion. Until the 1970s, Reunionese growers cultivated ' $R$ ' varieties locally bred by eRcane along with a few adapted foreign varieties (Boyer de La Giroday 1973). However, for the last 40 years, they only have cultivated ' $R$ ' varieties because of their superior agronomic performances. The high genetic potential of modern ' $R$ ' cultivars is the result of decades of progressive genetic improvement that has favored the selection of germplasm that is locally adapted and resistant or tolerant to major diseases. With the present-day cultivars (Table 4), the local industry achieves an average productivity of 9 tonnes of sugar per hectare. This average covers significant discrepancies between the least (6 tonnes/ha) and the most favorable producing areas (15 tonnes/ha).

\section{Progressive Development of the Breeding Program}

The organization and the size of the breeding program of eRcane remained largely unchanged until the end-1970s. Since that time, the program was carried out in the early selection stages at a single experimental station located at La Bretagne (LB) in the North humid coastal zone of the island, prior to advanced trials conducted on growers' farms scattered over all representative cultivation areas (Fig. 1). In 1977, a new eRcane station was set up in the East per-humid coastal region (Saint-Benoit, SB) to conduct a second full selection program from the very first clonal selection stage to increase the chances of selecting varieties suitable for this region. However, given the large number of target breeding environments in the industry, it was suggested several years later that comprehensive breeding programs be implemented, in even more environments to increase genetic gains across the whole industry (Bouvet et al. 1985). Hence, three new stations with a full selection program (from seedling stage) were gradually set up from the end of the 1980s in three additional specific environments: (i) in the dry West highlands (Vue-Belle, VB), characterized by cooler temperatures; (ii) in the West coastal irrigated zone (Etang-Salé, ES) and (iii) in the South-East coastal per-humid volcanic zone (SaintPhilippe, SP) (Boyer de la Giroday 1988). Due to urban encroachment, LB station located in the North humid coastal zone has been moved in the mid-1990s a few kilometers further in the location of La Mare (LM). At the end of the 2000s, eRcane's decentralized selection network was expanded by setting up two new stations with a full selection program: (i) one represents the particular conditions of the per-humid eastern highlands (Menciol, MC) and (ii) the other one the dry costal southwest region (Le Gol, GL) where cane is cultivated under a limited irrigation regime. Today this network consists of seven concurrent full selection programs conducted in the major sugarcane producing zones and represents a total of 200 hectares of variety experiments (www.ercane.re). Precise location of each selection site and detailed information about their climatic parameters and soil types are given in Guilly et al. 2017. As this selection program gradually expanded in size, eRcane also developed its hybridization program accordingly by making more bi-parental combinations and by producing more seedlings. Today these programs mobilize very significant experimental, technological and human resources on a permanent basis. In addition, eRcane benefits from collaborations with a network of cane growers for the final precommercial validation of its best varieties. For nearly a century of breeding efforts in

Table 4 List of current major cultivars in Reunion

\begin{tabular}{|c|c|c|c|c|}
\hline Variety & Parents & $\begin{array}{l}\% \text { of } \\
\text { cultivated } \\
\text { area }\end{array}$ & Main characteristics & Disease $(*)$ \\
\hline R570 & $\mathrm{H} 32 / 8560 \times \mathrm{R} 445$ & $36 \%$ & Large adaptation area, fairly high fiber content & $\begin{array}{l}\text { Resistant to smut and leaf scald, slightly } \\
\text { susceptible to orange rust }\end{array}$ \\
\hline R577 & $\mathrm{H} 39 / 3633 \times \mathrm{PR} 1059$ & $4 \%$ & Fairly adapted to drought, large diameter & Resistant to smut and leaf scald \\
\hline R579 & PR1028 × N8 & $36 \%$ & $\begin{array}{l}\text { Adapted to irrigated areas, good sucrose content, } \\
\text { low fiber content }\end{array}$ & $\begin{array}{l}\text { Resistant to smut and leaf scald, slightly } \\
\text { resistant to orange rust }\end{array}$ \\
\hline R582 & $\mathrm{R} 575 \times \mathrm{R} 570$ & $5 \%$ & $\begin{array}{l}\text { Good yield in irrigated areas, high vigor, good } \\
\text { sucrose content }\end{array}$ & $\begin{array}{l}\text { Slightly susceptible to smut, resistant to leaf } \\
\text { scald, susceptible to orange rust }\end{array}$ \\
\hline R584 & - & $4 \%$ & $\begin{array}{l}\text { Adapted to irrigated areas, large diameter, erect } \\
\text { shape }\end{array}$ & $\begin{array}{l}\text { Resistant to smut and leaf scald, intermediate } \\
\text { resistant to orange rust }\end{array}$ \\
\hline R585 & - & $8 \%$ & $\begin{array}{l}\text { High yield in difficult environment, very high } \\
\text { fiber content, smut susceptible }\end{array}$ & $\begin{array}{l}\text { Slightly susceptible to smut and leaf scald, } \\
\text { resistant to orange rust }\end{array}$ \\
\hline R586 & - & $4 \%$ & Adapted to drought and low temperatures & Susceptible to smut, resistant to leaf scald \\
\hline
\end{tabular}

*All cultivars in Reunion are resistant to brown rust (carry Brul gene) 
Reunion, land resource devoted to experimental selection has never been that important. The multiplicity of target environments of selection in Reunion allows selecting types of genotypes adapted to many different environments. This diversifying selection program gives opportunities to develop collaborations with some foreign producers (mainly located in West or East Africa countries) who do not have any breeding programs and wish to test some elite or commercial Reunionese varieties (or some specifically bred progeny) potentially adapted to their own cultivation environments (eRcane 2009; Barau et al. 2015).

\section{Continuous Breeding Efforts for Disease Resistance}

Since its inception in 1929, one of the key missions of the breeding program has been the control of important diseases, in order to keep the fields of the industry as healthy as possible. In Reunion, varietal resistance is the only viable and acceptable control strategy of the main diseases. Development of varietal resistance is sought through conventional genetic improvement and experimental selection. No phytosanitary treatment is used against any disease. This choice is due to economic reasons (controlling cane production costs), scientific motivations (not exerting selection pressures favoring the appearance of new strains of pathogens more aggressive) and environmental concerns (reducing the use of chemical treatments). The program succeeded in producing resistant or tolerant varieties, not only to mosaic (sugarcane mosaic virus), but also to most serious endemic diseases that have always affected local production (Hoarau 1965). These include smut (Sporisorium scitamineum), ratoon stunting disease (Leifsonia xyli subsp. xyli), leaf scald (Xanthomonas albilineans), chlorotic streak (Phytocercomonas venanatans) and gumming disease (Xanthomonas vasculorum). Gumming disease re-emerged in a severe epidemic in the late 1950s which affected many cultivars including R397 which occupied $60 \%$ of the cane area, as well as many elite breeding clones (D'Emmerez de Charmoy 1960). This epidemic, which was caused by a new virulent strain (Hoarau 1970), was efficiently controlled by breeding efforts a few years later. Brown rust (Puccinia melanocephala), which was first recorded on the Island in mid1960s, became important a decade later (Boyer de la Giroday et al. 1979). This disease was then efficiently controlled by breeding and selection of new resistant varieties. In particular, the famous R570 variety developed in Reunion in the 1980s which has become the most famous Reunionese variety abroad. The CIRAD group discovered in the cultivar R570 a major resistance gene, called Brul, which controls brown rust sporulation (Daugrois et al. 1996; Asgnaghi et al. 2004; Costet et al. 2012). This variety has been grown commercially or in germplasm collections in numerous geographical locations where brown rust exists (North and South America, Africa, Caribbean Islands, Mascarene Islands, etc.). At the present time, no breakdown of resistance to brown rust has been reported in this cultivar, making the Brul gene an exceptional example of durable resistance gene. Nowadays this major resistance gene has been identified in germplasm worldwide (Glynn et al. 2013; Racedo et al. 2013; Parco et al. 2014, 2017; $\mathrm{Li}$ et al. 2017) which are used as a sugarcane parental pool for crossing.

Today all endemic diseases in Reunion are under control thanks to breeding efforts aimed at developing varietal resistance in the local program and therefore local fields have been healthy for decades. However, orange rust (Puccinia kuehnii) recently detected in Reunion (Hubert et al. 2019) represents a new threat for the local sugarcane industry. This disease has been emerging strongly in many parts of the world for the past decade (Rott et al. 2017). In Reunion, in the wettest areas of the leeward coast, the prevalence of the disease among the current selection material appears relatively high (Dijoux 2020). As in the past in the face of previous diseases, breeders, geneticists and phytopathologists of eRcane and CIRAD organizations continue to collaborate in the development of disease control strategies based on varietal resistance.

\section{Germplasm maintenance and development}

To date, the germplasm collection is composed of 1018 clones among which $62 \%$ (631 clones) were locally bred hybrids (Table 5). The remaining $38 \%$ genotypes include (i) 306 foreign varieties imported from other breeding programs (coming from about 40 different origin among which Australia, South Africa, West Indies, Mauritius, USA and Brazil); (ii) 41 ancestral Saccharum spp. and Erianthus relatives; and (iii) 40 early-generation interspecific hybrids (EGISH) mainly locally bred (F1, BC1, $\mathrm{BC} 2$ ). The active working collection planted in flowering plots represents a subset of about 400 genotypes. Given its high cost of maintenance, this subset is managed in a dynamic ongoing process, involving discard of poorer performing parents in favor of new attractive ones. Selection of parents is mainly based on desirable trait values for cane yield, sucrose content and resistance to diseases but also for their ability to flower and to produce good progeny (for those already used in crossings). This working collection encompasses: (i) released varieties and all elite clones reaching the final multilocal selection stage; (ii) some clones discarded in previous advanced selection stages but with a good value for a particular trait of interest; (iii) foreign clones introduced in Reunion; (iv) EGISH from an ongoing local base broadening program; 
Table 5 eRcane germplasm collection

\begin{tabular}{ll}
\hline Species/collection & Number of genotypes \\
\hline Germplasm developed by eRcane & 631 \\
Imported germplasm & 306 \\
Saccharum officinarum & 24 \\
Saccharum spontaneum & 8 \\
Saccharum robustum & 2 \\
Saccharum sinense/barberi & 3 \\
Erianthus & 4 \\
F1, BC1, BC2 & 40 \\
Total (working collection) & $1018(400)$ \\
\hline
\end{tabular}

and (v) a few high-sucrose locally bred clones. Each year 80 new clones enter the working collection, which means that the latter is completely renewed every 5 years.

\section{Variety Exchanges Through 'Visacane'}

Variety exchanges between eRcane and foreign breeding programs for breeding purposes are mutually beneficial. Periodically eRcane reciprocally exchanges some elite clones with a few breeding programs (located in South Africa, Argentina, USA, Equator, China, Barbados, Mauritius, Brazil). Foreign clones introduced in Reunion are planted in the first replicated selection stage to study their adaptive performance and in germplasm collection to use them in crossings. In addition, each year eRcane exports some elite Reunionese varieties to partners located in countries who do not have any sugarcane breeding programs and are willing to test and use ' $R$ ' varieties for commercial production.

Any variety introduced in Reunion or exported abroad needs first to go through the international 'Visacane' quarantine of CIRAD located in Montpellier, Mainland France to secure safe exchange of sugarcane material free of pests and diseases and avoid the accidental introduction of new diseases in receiving countries. Visacane, CIRAD's sugarcane quarantine program, covers four main quarantine procedures: introduction of varieties, detection of pathogens, cleaning cane from pathogen if technology available and transfer of pathogen-free planting material (Guinet et al. 2015). The Visacane team aims to improve sugarcane adaptability, stability and sustainability. For that, sugarcane clones and related wild species with high levels of genetic diversity and originating from multiple sources are quarantined at Montpellier (France). This material is then sent to Visacane's partners with the respect of breeder's rights. For virus detection, the sugarcane quarantine process is intimately based on the knowledge and inventory of viruses potentially present in each imported clone. To better guarantee cane quality regarding viruses, the virome of sugarcane was recently investigated using viral metagenomics (Fernandez et al. 2020) resulting in the discovery of three uncharacterized sugarcane viruses (sugarcane white streak virus, sugarcane striate virus and sugarcane mild mosaic virus). The genetic diversity of these three viruses was assessed for improved diagnosis; hence, new protocols were developed and validated. An additional detection protocol targeting sugarcane bacilliform virus, (not considered as a quarantine organism by many countries and undiagnosed in quarantine) was also developed. These issues are critical to increase the sanitary guaranties of Visacane's sugarcane germplasm.

\section{Annual Crossing Program}

Every year, around 330 clones (about 200 female clones and 130 male clones) are used for crossing. Flowering in Reunion takes place from the beginning of May to the end of June. Only natural flowering is used in Reunion. Panicles are harvested in specific flowering plots located in the favorable stations (see Fig. 1) of La Mare (North coast), Saint-Benoît (East coast), Saint-Philippe (South-East coast). Controlled crosses are made in glasshouse facility located in the central station of La Bretagne (North Coast) using Hawaiian solution (Heinz and Tew 1987) for panicle conservation and development during two weeks.

Each year about 5000 panicles are harvested in order to make 2500 crosses. Crossing objectives include (i) combination between Reunionese elite clones issued from the same selection environment for improved local adaptation (Thong-Chane et al. 2016); (ii) experimental crosses between foreign varieties with locally bred ones; (iii) specific crosses for a high-sucrose experimental recurrent program; and (iv) specific crosses for a small base broadening program using $S$. spontaneum. These latter ongoing pre-breeding activities constitute long-term improvement efforts (eRcane 2009). They aim to incorporate into the conventional germplasm new wild genes controlling some well-known agronomic attributes brought by $S$. spontaneum (robustness, ratooning ability, fiber content, resistance to abiotic stresses and some biotic ones). Currently eRcane program creates and select annually $2000 \mathrm{~F} 1$ (20 crosses), 2000 BC1 (20 crosses) and 7000 BC2 (70 crosses) using for crosses $S$. spontaneum or EGISH germplasm so far available (Table 5). To reinforce and keep broadening this specific program, some new $S$. spontaneum accessions from the ISSCT International Collection in Miami will be received next year.

Seed maturation lasts between three to four weeks. Fuzz is dried at $40{ }^{\circ} \mathrm{C}$ during two days before packing in plastic 
bags and freeze conservation $\left(-16 \mathrm{C}^{\circ}\right)$. Fuzz is sown in a germination room for 2 days at $32{ }^{\circ} \mathrm{C}$, and resulting seedlings are placed in glasshouse for one month before hardening outside. Then, the populations of seedlings are transplanted in field nurseries. Each annual nursery regularly supplies a pipeline of selection (Dumont et al. 2019) with new experimental material, which thus operates continuously.

In addition to the above activities, the eRcane team has developed long-term partnerships to bring its expertise in variety development programs to assist some sugar producers abroad. This includes partners who are interested in developing selection programs in their own environments from crosses made in Reunion with appropriate genetic resources. For these international partnerships, eRcane produces and exports specific additional fuzz along together with customized technical and scientific assistance.

\section{Selection Program of Reunion}

\section{Key Objectives}

The main objective of the eRcane breeding program is to select varieties suited to the major agroclimatic regions of Reunion Island where sugarcane is cultivated (Fig. 1). In a context where response of varieties for their economic profitability is little correlated between many selection sites (Guilly et al. 2017), the selection strategy is firstly oriented toward selecting genotypes adapted to specific targeted environments, to enhance the mean productivity of the whole cane industry, rather than selecting for broad adaptation. Key criteria of selection include high sugar productivity (cane yield and sucrose content), good resistance levels to major diseases present locally (smut, brown and orange rusts, gumming and leaf scald diseases), low flowering propensity and a good ratooning ability of varieties after successive annual harvests. This latter criterion and disease resistance are very important for growers. Most growers prefer varieties that provide sustainable yields for many years, as the average number of ratoon crops in commercial fields is $10-12$. Hence, selection takes place in ratoon crops from the first clonal selection stage and the number of ratoon crops taken into account by breeders regularly increases with the successive selection stages (Table 3).

\section{Organization of the Selection Scheme}

Each year, 100000 seedlings are dispatched among the seven selection programs (approx. 15000 new clones per site). The seven selection sites correspond to seven contrasting cultivation areas (Fig. 1): LM corresponds to the humid coastal zone with a partial hydric stress period; SB to the per-humid coastal zone; MC to the over-humid zone of East high land; SP to the pluvial zone of the south, with very low chemical fertility; ES to the favorable coastal zone conducted with full irrigation; GL to the same environment conducted with hydric stress $(50 \%$ of the hydric needs) and VB to the dry and cold highlands. Seedling populations of each site start a local four-stage selection process (see Table 3 and Sect. 5.4). At the end of the selection scheme, only the best genotypes from each site enter the final selection stage (fifth) that consists of a multienvironment trial (MET). This five-stage selection sequence is characterized by a gradually decreasing number of candidate lines tested in trials progressively more robust (larger plot size, more replicates and crop-cycles). Table 3 gives a summary overview of eRcane selection scheme in terms of experimental designs used, plot areas, replicates and crop-year numbers, selection rates and selection criteria. In each of the seven breeding sites, the last three stages of selection, which consist of repeated trial designs, always contain the $2-4$ best cultivars used by the growers in the area to help assess commercial potential of the new experimental clones.

\section{Traits Examined and Protocols of Measurements}

As a general rule, selection conducted most always combines: (i) a visual assessment of all candidate genotypes close to the end of the last ratoon crop and (ii) data of tonnes of cane per hectare (TCH) and recoverable sugar (RS) of all genotypes recorded in plant crop and all ratoon crops, which allows calculation of an economic index (EI) for each genotype that represents a multi-year farming profit.

The visual assessment is achieved based on qualitative observations and/or discrete ratings of some agronomic traits. These traits include morphological components of cane yield (stalk number, stalk diameter, stalk height), appearance/behavior traits (flowering rate, erectness/lodging of stalks, self-trashing, canopy shape, etc.), ratoon ability and visual symptoms of local major diseases (mainly smut, orange and brown rust, leaf scale, gumming). These visual assessments are not the subject of any statistical analysis. They simply allow identification of varieties with repeated agronomic defects (across replicates) which would adversely impact growers (in a frequent situation of manual harvesting) or even prohibit commercial viability (disease, high lodging), despite possibly interesting performances for TCH, RS and EI traits.

The latter three quantitative traits (TCH, RS and EI) are measured in all replicated selection stages (3,4 and 5) and subject to statistical analyses based on models adapted to the trial designs used. In all trials, individual variety plots 
are manually harvested and all millable stalks are weighed using a digital scale mounted on a tractor. Cane weight divided by plot area allows estimating TCH. For the assessment of sugarcane quality traits, the eRcane breeding program possesses a modern laboratory facility equipped with a semiautomatic Near-Infra-Red Spectroscopy (NIRS) device (Bruker Optik $\mathrm{GmbH}$ ). This analysis system allows a high-throughput and cost-effective analysis of all basic quality parameters (fiber \%cane, Pol \%juice, Brix \%juice, and derived purity, Pol \%cane) thanks to accurate in-house calibrations (Roussel et al. 2015). These NIRS-based quality parameters are routinely acquired on all trials of the three replicated selection stages (3, 4 and 5). RS is calculated from these NIRS-based fiber, Brix and Pol predictions according to conventional calculations used in the local cane industry adapted from Saranin (1986). The conventional economic index (EI) used by eRcane to rank the cultivation merit of candidate genotypes is calculated from the $\mathrm{TCH}$ and $\mathrm{RS}$ using the formula $\mathrm{EI}=\mathrm{TCH} \times(\mathrm{RS}-4)$, being indicative of farming profit net of production costs (Hugot 1958).

\section{Successive Clonal Selection Stages}

\section{Stage 1: Seedlings Stage}

At this first experimental stage, seedlings are planted in a partially replicated family plot design (80 progenies per family). The selection process is a combined family and within-family selection to optimize genetic gains and costs (Kimbeng and Cox 2003). Due to human and logistical constraints not allowing measurement of family $\mathrm{TCH}$ values, selection is conducted using a visual rating of cane yield based on a semi quantitative scale that reflects family vigor and the disease resistance. Significant correlations between visual ratings and subsequent performances in the next clonal stage have been established elsewhere (Jackson 2018), even with sugar content (more vigorous seedlings tend to have higher sugar content in the next stage). Intensity of seedlings selection within family is proportional to this family rating and varies between stringent $(5 \%)$ to liberal $(30 \%)$ thresholds. A total of 2,000 clones are promoted in each selection site to the next stage.

\section{Stage 2: One-row Stage}

The 2,000 clones are tested in a single 3-m row in an unreplicated layout with a control variety regularly interposed among plots of unreplicated test clones. This experiment is a sort of grid-plot design. The control variety, which represents $10 \%$ of the total plot number, allows adjustment of observations based on field heterogeneity in order to improve selection decisions. The control variety is either an ' $\mathrm{R}$ ' variety or a susceptible variety to some major diseases that ensures pathogen spread throughout the experiment. Clones are harvested in plant-cane without any measurement or observations. Selection is made in first ratoon crop based on visual assessments including disease symptom observations (as detailed below) and a field brix evaluation, which approximates an ERS value. A total of 120 clones are selected in each selection site which represents a rather stringent selection intensity $(6 \%)$.

\section{Stage 3: Two-row Stage}

The 120 selected clones in each site are planted in an alpha design (Patterson and Williams 1976) with two complete adjacent replicates containing ten to 12 incomplete blocks (IB) of between 12 to 10 clones, respectively. Basic variety plots consist of two rows of $5 \mathrm{~m}$ length (i.e., $15 \mathrm{~m}^{2}$ ). Alpha designs are used to increase experimental precision to the extent that variety plots within IBs are more uniform than between IBs. In the present early-generation trial (still many varieties in the race to be compared), these designs are more efficient than conventional randomized complete block designs (RCBD) (Patterson and Hunter 1983; Yau et al. 1997), particularly in some fields of eRcane which encompass spatial heterogeneity. Selection is based on visual observations, carried out at the end of the second ratoon crop at twelve months. TCH, RS and EI are measured across three successive crop cycles. A set of 25 elite clones is selected in each selection site, i.e., a selection rate of $14 \%$.

\section{Stage 4: Three-row Stage}

The 25 selected clones in each site are planted in a RCBD with three complete replicates in which the basic variety plot consists of three rows of $10 \mathrm{~m}$ length (i.e., $45 \mathrm{~m}^{2}$ ). Similarly as in the previous stage, selection is made at the end of the second ratoon crop and is based on the combination of visual assessments and TCH, RS and EI performances measured on three successive crop cycles. Only clones showing similar or superior results than the variety controls are selected for the final stage. This stage generally contains three to five experimental clones per site (i.e., a selection rate of $16 \%$ ). One year of seed multiplication separates this stage from the next one.

\section{Stage 5: Multienvironment Stage}

This final multienvironment trial (MET) consists in testing about 25 elite varieties (the best three to five best varieties of each selection site) across the seven selection sites plus one-farm trials located in contrasted environments. This MET stage allows evaluation of genotype-by-environment 
interaction for $\mathrm{TCH}, \mathrm{RS}$ and $\mathrm{EI}$ traits, performance of variety in each site and their stability across sites. This stage consists of RCBD with four complete replicates, where individual variety plots consist of three rows of $10 \mathrm{~m}$ length (i.e., $45 \mathrm{~m}^{2}$ ). Similarly, as in the two previous stages, selection is made at the end of the second ratoon crop and is based on the combination of visual assessments and $\mathrm{TCH}, \mathrm{RS}$ and EI performances measured on four successive crop cycles.

At this final selection stage, the 25 elite clones are also subjected to inoculated-based disease resistance trials for three diseases, which can cause severe losses to susceptible varieties: smut, leaf scald and gumming diseases. Natural inoculum in selection fields may be low and irregular in space and time. Therefore, some apparently elite varieties susceptible to one of these three diseases may escape significant natural infection in the first four selection stages. For each disease, the 25 elite varieties are tested in a RCBD trial composed of three to six complete replicates. Smut testing is based on the dip inoculation method of stalk cuttings in a spore suspension before planting, leaf scald on the decapitation technique of the stalks above growing point (Rott et al. 1997) and gumming with spreading rows of a highly susceptible variety. These inoculated disease experiments include check varieties known to be either highly resistant, intermediate or very susceptible, as comparators. The high artificial pathogen pressure allows a reliable screening/ranking of the test varieties for their resistance level in comparison with well-known controls.

Genotypes recommended for release are expected to provide higher sugar yield than current commercial varieties and/or a higher resistance level to one or several major diseases of Reunion Island. After the final MET selection stage and disease resistance trials, the few best varieties still in the race in each environment are tested in precommercial trials of several hectares with growers who are part of eRcane network. These final collaborations enable the potential of the very best varieties to be validated on a large scale under growers' environmental conditions and cultural practices. Precommercial trials also allow the adaptation of varieties to be tested on a broader environments and facilitate a commercial promotion and recommendation of a new variety in case of a release decision.

\section{Supporting Genetics Research}

eRcane and CIRAD scientific teams have long-standing collaborations in applied molecular genetics for variety improvement. This collaboration first focused on genetic mapping studies (Hoarau et al. 2001; Raboin et al. 2006) and on QTL analyses of yield components (Hoarau et al. 2002b), resistance to brown rust (Daugrois et al. 1996; Asnaghi et al. 2004; Costet et al. 2012), smut (Raboin et al. 2003) and the borer Chilo sacchariphagus (Nibouche et al. 2012). All these studies were carried out with the cultivar R570 (from Reunion Island) and its progeny, and this clone has now been a model variety for numerous studies conducted by CIRAD for two decades. These studies revealed a complex quantitative genetic architecture for most traits, with the exception of rust resistance for which a major resistance gene was found (Daugrois et al. 1996; Costet et al. 2012). The collaborations then focused on the study of panels of varieties of relatively modest size: (i) to prospect for genes/alleles responsible for agronomic traits (Debibakas et al. 2014; Gouy et al. 2015) using genomewide associations studies (GWAS) approaches; and (ii) to test models of genomic selection (GS) to predict numerous agronomic traits (Gouy et al. 2013). These pilot studies allowed testing and adapting analytical methodologies to the complex genetic context of sugarcane (Hoarau et al. 2007). Although conducted with a density of markers still weakly covering the large polyploid genome of sugarcane on variety panels of modest size, these studies have produced encouraging results, which demonstrated the feasibility of developing useful commercial applications in sugarcane breeding based on genomics technologies. The current collaborative work between eRcane and CIRAD aims to move from these first pilot studies to finalized applications integrated into the breeding program. To do so, large populations of experimental varieties are currently characterized for many useful agronomic traits. Their genome will be densely marked with a Next Generation Sequencing (NGS) technology producing high-throughput Single Nucleotide Polymorphism (SNP) markers to test GWAS and GS applications fully integrated into the breeding program.

The complex genome of sugarcane, with its high ploidy level and interspecific origin (Hoarau et al. 2007), has frequently hindered advances in molecular breeding applications. To successfully develop productive genomic breeding applications, some key ingredients are required. These include (i) inference of meaningful SNP markers from Next Generation Sequencing data, utilizing expertise in bioinformatics and statistics (Garsmeur et al. 2018); (ii) accurate assessment of agronomic trait data from large and representative populations of clones; and (iii) expertise in genetics and statistical modeling of experimental data to smartly exploit phenotypic and genotypic data together. Successful development of genomic breeding applications aimed at variety improvement will require close scientific collaborations among breeders, pathologists, quantitative geneticists, molecular biologists, biometricians and computer scientists. 


\section{Declarations}

Conflict of interest The authors declare no conflict of interests regarding the publication of this paper.

Open Access This article is licensed under a Creative Commons Attribution 4.0 International License, which permits use, sharing, adaptation, distribution and reproduction in any medium or format, as long as you give appropriate credit to the original author(s) and the source, provide a link to the Creative Commons licence, and indicate if changes were made. The images or other third party material in this article are included in the article's Creative Commons licence, unless indicated otherwise in a credit line to the material. If material is not included in the article's Creative Commons licence and your intended use is not permitted by statutory regulation or exceeds the permitted use, you will need to obtain permission directly from the copyright holder. To view a copy of this licence, visit http://creativecommons. org/licenses/by/4.0/.

\section{References}

Asnaghi, C., D. Roques, S. Ruffel, C. Kaye, J.Y. Hoarau, H. Telismart, J.C. Girard, L.M. Raboin, A.M. Risterucci, L. Grivet, and A. D'Hont. 2004. Targeted mapping of a sugarcane rust resistance gene (Brul) using bulked segregant analysis and AFLP markers. Theoretical and Applied Genetics 108 (4): 759-764.

Barau, L., A. Thong-Chane and B. Siegmund. 2015. eRcane regional selection: success in Reunion island and new developments in Central and West Africa. In: ISSCT abstracts of the $11^{\text {th }}$ Germplasm and Breeding and $8^{\text {th }}$ Molecular Biology workshops. Pushing the frontiers of sugarcane improvement. ISSCT, StGilles, Reunion Island 1-5 June 2015 [BO16].

Bouvet, P.E., D.J. Heinz, K. Shoji, A., Stewart Li and G. Morgan. 1985. La production de canne à La Réunion, bilan et persepctives. Rapport de la mission des experts hawaiiens. ABA International, $180 \mathrm{p}$.

Boyer de la Giroday, E. 1973. Variétés de canne cultivées à La Réunion. Revue Agricole Et Sucrière De L'ile Maurice 52 (4): 232-238.

Boyer de la Giroday, E. 1988. Le CERF (Le centre d'Essai, de Recherche et de Formation). Panaroma agricole et sucrier. Actes $d u 3^{\text {ème }}$ congrès international de l'ARTAS, pp. 62-64.

Boyer de la Giroday, E., M. Chatenet, and P. Baudin. 1979. Rusts of sugarcane and some gramineae in Reunion. Agronomie Tropicale 34: 372-376.

Caderby, E., C. Roussel, and A. Petit. 2014. La canne à sucre: une plante aux multiples perspectives. Industries Alimentaires Et Agricoles, Juillet-Aout 2014: 8-11.

Costet, L., L. Le Cunff, S. Royaert, L.M. Raboin, C. Hervouet, L. Toubi, H. Telismart, O. Garsmeur, Y. Rousselle, J. Pauquet, S. Nibouche, J.C. Glaszmann, J.Y. Hoarau, and A. D'Hont. 2012. Haplotype structure around Bru1 reveals a narrow genetic basis for brown rust resistance in modern sugarcane cultivars. Theoretical and Applied Genetics 125 (5): 825-836.

D'Emmerez de Charmoy, D. 1929. Rapport sur ma mission à Coimbatore pour l'étude de la production rationnelle de variétés de canne selon les nouvelles méthodes. Bulletin de la Chambre d'Agriculture et des comices agricoles. Mois d'avril : 17-23.

D'Emmerez de Charmoy, D. 1953. Etudes sur de nouvelles variétés de canne à sucre à La Réunion. L' Agronomie Tropicale III (4): $417-425$.
D’Emmerez de Charmoy, D. 1960. Un aspect imprévu de la gommose à La Réunion. Revue Agricole Et Sucrière De L'ile Maurice 39: 229-236.

D'Emmerez de Charmoy, D. 1962. Sélection de la canne à sucre à La Réunion. Nouveautés Et Tendances Futures. L'agronomie Tropicale 7-8: 546-559.

Daugrois, J.H., L. Grivet, D. Roques, J.Y. Hoarau, H. Lombard, J.C. Glaszmann, and A. D'Hont. 1996. A putative major gene for rust resistance linked with a RFLP marker in sugarcane cultivar 'R570.' Theoretical and Applied Genetics 92 (8): 1059-1064.

Débibakas, S., S. Rocher, O. Garsmeur, L. Toubi, D. Roques, A. D'Hont, J.Y. Hoarau, and J.H. Daugrois. 2014. Prospecting sugarcane resistance to Sugarcane yellow leaf virus by genomewide association. Theoretical and Applied Genetics 127 (8): $1719-1732$.

Dijoux J. 2020. Emergence de la rouille orangée de la canne à sucre (Puccinia kuehnii) à La Réunion : Caractérisation de son impact sur le programme local de création et de sélection variétales. Master dissertation. Montpellier Sup Agro, 136 p.

Dumont, T., A. Thong-Chane, L. Barau, B. Siegmund, and J.Y. Hoarau. 2019. Genetic variabilities and genetic gains for yield components in regional sugarcane breeding programmes on Réunion Island. Sugar Tech 21 (6): 868-878.

eRcane 2009. Enhancing the value of sugarcane. Annual report 2007-2009. Reunion Island, $74 \mathrm{p}$.

Fernandez, E., R. Ferdinand, D. Filloux, I. Guinet, C. Julian, P. Rott, P. Roumagnac, and J.-H. Daugrois. 2020. Improvements in virus detection at CIRAD's sugarcane quarantine using both viral metagenomics and PCR-based approaches. Sugar Tech 22: 498-503.

Garsmeur, O., G. Droc, R. Antonise, J. Grimwood, B. Potier, K. Aitken, J. Jenkins, G. Martin, C. Charron, C. Hervouet, L. Costet, N. Yahiaoui, A. Healey, D. Sims, Y. Cherukuri, A. Sreedasyam, A. Kilian, A. Chan, M.A. Van Sluys, K. Swaminathan, C. Town, H. Bergès, B. Simmons, J.C. Glaszmann, E. Van der Vosser, R. Henry, J. Schmutz, and A. D'Hont. 2018. A mosaic monoploid reference sequence for the highly complex genome of sugarcane. Nature Communications 9 (1): 1-10.

Glynn, N.C., C. Laborde, R.W. Davidson, M.S. Irey, B. Glaz, A. D'Hont, and J.C. Comstock. 2013. Utilization of a major brown rust resistance gene in sugarcane breeding. Molecular Breeding 31 (2): 323-331.

Gouy, M., Y. Rousselle, D. Bastianelli, P. Lecomte, L. Bonnal, D. Roques, J.C. Efile, S. Rocher, J.H. Daugrois, L. Toubi, S. Nabeneza, C. Hervouet, H. Telismart, M. Denis, A. ThongChane, J.C. Glaszmann, J.Y. Hoarau, S. Nibouche, and L. Costet. 2013. Experimental assessment of the accuracy of genomic selection in sugarcane. Theoretical and Applied Genetics 126 (10): 2575-2586.

Gouy, M., Y. Rousselle, A. Thong-Chane, A. Anglade, S. Royaert, S. Nibouche, and L. Costet. 2015. Genome wide association mapping of agro-morphological and disease resistance traits in sugarcane. Euphytica 202 (2): 269-284.

Guilly, S., T. Dumont, A. Thong-Chane, L. Barau, and J.Y. Hoarau. 2017. Analysis of multi-environment trials (MET) in the sugarcane breeding program of Reunion Island. Euphytica 213 (9): 213

Guinet, I., J.C. Girard, P. Roumagnac, J.H. Daugrois, and P. Rott. 2015. Visacane: An innovative quarantine tool for the exchange of pest and disease-free sugarcane germplasm. International Sugar Journal 117 (1404): 890-896.

Heinz, D.J., and T.L. Tew. 1987. Hybridization procedures. In Sugarcane improvement through breeding, ed. D.J. Heinz, 313-342. Amsterdam: Elsevier Press. 
Hoarau, M. 1965. Sugar cane diseases in Réunion island. Proceedings of the International Society of Sugar Cane Technologists 12: $1232-1235$.

Hoarau, M. 1970. Gommose (Xanthomonas vascularum). Annual Report of Institut de Recherches en Agronomie Tropicale, Agence de La Réunion 35-61.

Hoarau, J.Y., B. Offmann, A. D'Hont, A.M. Risterucci, D. Roques, J.C. Glaszmann, and L. Grivet. 2001. Genetic dissection of a modern sugarcane cultivar (Saccharum spp.). I. Genome mapping with AFLP markers. Theoretical and Applied Genetics 103 (1): 84-97.

Hoarau, J.Y., J. Payet and M. Hellmann. 2002a. La lutte contre la maladie de la mosaïque de la canne à sucre à La Réunion. L'action agricole de la Station de Génétique de la Bretagne. In: Colloque sur les Perspectives de développement de la canne à sucre en milieu insulaire, Stella Matutina, Réunion. La canne une passion à partager: rencontres internationales pluridisciplinaires 2-5 octobre 2002. Muséum Stella Matutina. Piton Saint-Leu, Réunion, 1 Cd-Rom, 13 p.

Hoarau, J.Y., L. Grivet, B. Offmann, L.M. Raboin, J.P. Diorflar, J.P. Payet, M. Hellmann, A. D'Hont, and J.C. Glaszmann. 2002b. Genetic dissection of a modern sugarcane cultivar (Saccharum spp.). II. Detection of QTLs for yield components. Theoretical and Applied Genetics 105 (6-7): 1027-1037.

Hoarau, J.Y., G. Souza, A. D'Hont, M. Menossi, L.R. Pinto, A.P. Souza, L. Grivet, M.C.F. Menck, E.C. Cesar, and M. Vincentz. 2007. Sugarcane: A tropical crop with a highly complex genome. In Functional plant genomics, ed. J.F. Morot-Gaudry, P. Lea, and J.F. Briat, 481-499. Enfield: Science Publishers.

Hoarau, J.Y., A. Thong-Chane, L. Barau, and T. Dumont. 2019. Comparison between randomized complete-block and alpha designs in sugarcane variety trials in the light of a spatial modelling of fertility trends. Proceedings of the International Society of Sugar Cane Technologists 30: 121-127.

Hoarau, J.Y., T. Dumont, X. Wei, P. Jackson and A. D'Hont. 2021. Applications of quantitative genetics and statistical analyses in sugarcane breeding. Submitted (Sugar Tech).

Hubert, J., C. Jeandel, L. Costet, B. Hostachy, A.S. Dupuis, A. Coddeville, L. Barau, and R. Ioos. 2019. First report of orange rust caused by Puccinia kuehnii on sugarcane on the Island of Reunion. Plant Disease 103 (11): 2962.

Hugot, E. 1958. Critère et formule de comparaisons entre champs, parcelles, variétés ou traitements de cannes. Revue Agricole Et Sucrière De L'ile Maurice 37: 212-216.

Jackson, P.A. 2018. What is the optimal selection intensity of seedlings (stage 1) in sugarcane breeding programs? International Sugar Journal 120 (1435): 542-546.

Kimbeng, C.A., and M.C. Cox. 2003. Early generation selection of sugarcane families and clones in Australia: A review. Journal of the American Society of Sugar Cane Technologists 23: 20-39.

Kopp A., and D. d'Emmerez de Charmoy. 1932. Situation actuelle de la mosaïque de la canne à sucre à la Réunion. Bulletin $N^{\circ} 3$, Station Agronomique. Ile de la Réunion, p 11-20

Li, W.F., X.Y. Wang, Y.K. Huang, R.Y. Zhang, H.L. Shan, J. Yin, and Z.M. Luo. 2017. Molecular detection of Bru1 gene and identification of brown rust resistance in Chinese sugarcane germplasm. Sugar Tech 19 (2): 183-190.

Nibouche, S., L.M. Raboin, J.Y. Hoarau, A. D'Hont, and L. Costet. 2012. Quantitative trait loci for sugarcane resistance to the spotted stem borer Chilo sacchariphagus. Molecular Breeding 29 (1): 129-135.
Parco, A.S., M.C. Avellaneda, A.H. Hale, J.W. Hoy, C.A. Kimbeng, M.J. Pontif, K.A. Gravois, and N. Baisakh. 2014. Frequency and distribution of the brown rust resistance gene Bru1 and implications for the Louisiana sugarcane breeding programme. Plant Breeding 133: 654-659.

Parco, A.S., A.L. Hale, M.C. Avellaneda, J.W. Hoy, C.A. Kimbeng, M.J. Pontif, P.H. McCord, T. Ayala-Silva, J.R. Todd, and N. Baisakh. 2017. Distribution and frequency of Bru1, a major brown rust resistance gene, in the sugarcane world collection. Plant Breeding 136 (5): 637-651.

Patterson, H.D., and E.A. Hunter. 1983. The efficiency of incomplete block designs in National List and Recommended List cereal of variety trials. The Journal of Agricultural Science 101 (2): 427-433.

Patterson, H.D., and E.R. Williams. 1976. A new class of resolvable incomplete block designs. Biometrika 63: 83-92.

Pouzet, D., P.F. Chabalier, and P. Legier. 1997. Diagnostic de fertilité des sols et conseils en fertilisation des principales cultures réunionnaises. Agriculture Et Développement 16: 18-37.

Raboin, L.M., J.Y. Hoarau, L. Costet, H. Telismart, J.C. Glaszmann, and A. D'Hont. 2003. Progress in genetic mapping of sugarcane smut resistance. Proceedings of the South African Sugar Technologists' Association 77: 134-140.

Raboin, L.M., K.M. Oliveira, L. Lecunff, H. Telismart, D. Roques, M.K. Butterfield, J.Y. Hoarau, and A. D'Hont. 2006. Genetic mapping in sugarcane, a high polyploid, using bi-parental progeny: identification of a gene controlling stalk colour and a new rust resistance gene. Theoretical and Applied Genetics 112: $1382-1391$.

Racedo, J., M.F. Perera, R. Bertani, C. Funes, V. González, M.I. Cuenya, D. Angélique, B. Welin, and A.P. Castagnaro. 2013. Bru 1 gene and potential alternative sources of resistance to sugarcane brown rust disease. Euphytica 191 (3): 429-436.

Rott, P., I.S. Mohamed, P. Klett, D. Soupa, A. de Saint-Albin, P. Feldmann, and P. Letourmy. 1997. Resistance to leaf scald disease is associated with limited colonization of sugarcane and wild relatives by Xanthomonas albilineans. Phytopathology 87: 1202-1213.

Rott, P., S. Sood, J.C. Comstock, R.N. Raid, N.C. Glynn, R.A. Gilbert and H.S. Sandhu. 2017. Sugarcane orange rust. Agronomy Department, UF/IFAS Extension, SS-AGR-378 https://edis.ifas.ufl.edu/sc099

Roussel, C., F.R., Warembourg, F. Davrieux, J. Bernard and C. Poser. 2015. Development of NIRS method for routine assessment of sugarcane quality in Reunion Island. In: ISSCT abstracts of the $11^{\text {th }}$ Germplasm and Breeding and $8^{\text {th }}$ Molecular Biology workshops. Pushing the frontiers of sugarcane improvement. ISSCT, St-Gilles, Reunion Island 1-5 June 2015 [BO12].

Saranin, A.P. 1986. The press method of sugarcane analysis. Proceedings of the Australian Society of Sugarcane Technologists 8: 33-42.

Thong-Chane, A., J.B. Sinama, C. Boisbineuf, and L. Barau. 2016. Are elite sugarcane varieties also parents in their zone of adaptation? Proceedings of the International Society of Sugar Cane Technologists 29: 72-75.

Publisher's Note Springer Nature remains neutral with regard to jurisdictional claims in published maps and institutional affiliations. 